\title{
Verschraalde zorg? : over autonomie, identiteit en zingeving in de zorg voor hulpbehoevende ouderen
}

Citation for published version (APA):

ter Meulen, R. H. J. (1994). Verschraalde zorg? : over autonomie, identiteit en zingeving in de zorg voor hulpbehoevende ouderen. Radboudstichting Wetenschappelijk Onderwijsfonds.

https://doi.org/10.26481/spe.19941202rm

Document status and date:

Published: 02/12/1994

DOI:

10.26481/spe.19941202rm

Document Version:

Publisher's PDF, also known as Version of record

\section{Please check the document version of this publication:}

- A submitted manuscript is the version of the article upon submission and before peer-review. There can be important differences between the submitted version and the official published version of record.

People interested in the research are advised to contact the author for the final version of the publication, or visit the DOI to the publisher's website.

- The final author version and the galley proof are versions of the publication after peer review.

- The final published version features the final layout of the paper including the volume, issue and page numbers.

Link to publication

\footnotetext{
General rights rights.

- You may freely distribute the URL identifying the publication in the public portal. please follow below link for the End User Agreement:

www.umlib.nl/taverne-license

Take down policy

If you believe that this document breaches copyright please contact us at:

repository@maastrichtuniversity.nl

providing details and we will investigate your claim.
}

Copyright and moral rights for the publications made accessible in the public portal are retained by the authors and/or other copyright owners and it is a condition of accessing publications that users recognise and abide by the legal requirements associated with these

- Users may download and print one copy of any publication from the public portal for the purpose of private study or research.

- You may not further distribute the material or use it for any profit-making activity or commercial gain

If the publication is distributed under the terms of Article $25 \mathrm{fa}$ of the Dutch Copyright Act, indicated by the "Taverne" license above, 
why

092
Universiteitsblbllotheek

Rijksuniversiteit Limburg

Postbus 616

6200 MD Maastricht

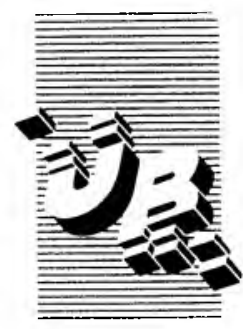

De uitleentermijn verstrijkt op

\section{$13-02-95$ \\ -6 JU11 1005 \\ $-7 \Gamma \div 3.9 ? 31$

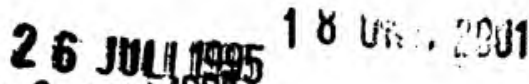 \\ 28 JULi 9995}

O 1 AUG. 1996

17 SEP. 1996

Gelieve deze publicatie tijdig te retourneren of (telefonisch) verlen ging van de uitleentermijn aar vragen. 


\section{Verschraalde zorg ?}

over autonomie, identiteit en zingeving

in de zorg

voor hulpbehoevende ouderen

\section{Rede}

uitgesprokèn bij de aanvaarding van het ambt van

Bijzonder Hoogleraar Wijsbegeerte in Relatie tot

de Katholieke Levensbeschouwing

aan de Rijksuniversiteit Limburg te Maastricht

op vrijdag 2 december 1994

door

Dr. R.H.J. ter Meulen 
125404344

Bibliotheek

R.U. Limburg 


\section{Mijnheer de rector magnificus, geachte collegae, studenten en toehoorders}

Steeds meer mensen worden oud, steeds meer mensen worden zeer oud. Voor veel mensen is dit goed nieuws, voor velen is dit nieuws slecht. Het langere leven gaat immers gepaard met een toenemende kans op langdurige invaliditeit door chronische ziekten en handicaps. Ziekten van het bewegingsapparaat, neurologische aandoeningen waaronder de ziekte van Alzheimer, chronisch harten vaatlijden en kanker maken de oude dag niet zelden tot de minst aangename periode van de levensloop. Aan deze lijst kunnen worden toegevoegd visuele en akoestisch stoornissen, psychiatrische stoornissen (depressie), prostaatlijden, incontinentie en eenzaamheid.

Ten gevolge van de toenemende kans op deze aandoeningen en gebreken zijn ouderen, en vooral zij die de tachtig zijn gepasseerd, aangewezen op de hulp van anderen. Dat kunnen professionele hulpverleners zijn in verpleeghuis, ziekenhuis, bejaardenhuis of thuishulp. Het kunnen ook familie, naasten of buren zijn, vaak samengebracht onder de noemer 'mantel'. Deze langdurige en vaak blijvende afhankelijkheid van anderen staat haaks op de in onze westerse cultuur $z o$ innig gekoesterde waarde van zelfbepaling ofwel autonomie. Wij willen zo lang mogelijk onafhankelijk zijn en ons eigen leven blijven inrichten, ongestoord door de, al dan niet welgemeende, bemoeienissen van anderen. Daarnaast hebben wij er moeite mee om anderen lastig te vallen met onze problemen en afhankelijkheid. Zo willen veel ouderen die op dagelijkse zorg zijn aangewezen hun kinderen daarmee niet belasten. Dit verschijnsel wordt in de angel-saxische literatuur wel aangeduid met de term 'counterdependence': de autonomie wordt in onze cultuur zo sterk gewaardeerd dat ouderen zich verplicht voelen zo lang mogelijk onafhankelijk te blijven en geen hulp aan te nemen van anderen.

In het beleid ten aanzien van de zorg voor hulpbehoevende ouderen vormt deze behoefte aan autonomie een belangrijk uitgangspunt. Het streven is om ouderen zo lang mogelijk thuis te houden of zo snel mogelijk naar huis te laten gaan als verblijf in een ziekenhuis of verpleeghuis niet meer strikt noodzakelijk is. In het verpleeghuis wil men ouderen de gelegenheid geven zelfstandig te blijven en mee 
te praten over behandeling en verblijf. In de ziektekostenverzekering zien we de opkomst van het cliëntgebonden budget, dat ouderen (en andere groepen zoals verstandelijk gehandicapten en jongere chronisch zieken) in staat wil stellen zelf keuzes te maken over de voor hen noodzakelijke zorgvoorzieningen. Hoewel bij sommige van deze beleidsvormen (met name het substitutiebeleid) ook economische motieven een rol spelen, wil men hiermee vooral toch tegemoet komen aan de behoefte aan een zo groot en zo lang mogelijke zelfstandigheid en onafhankelijkheid.

\section{Autonomie in het verpleeghuis}

Hoewel velen tegenwoordig de mond vol hebben van autonomie, vraagt men zich zelden af wat dit begrip precies inhoudt. Zo heeft men het vaak over 'zelfbeschikking', 'het maken van eigen keuzen', 'onafhankelijkheid' of 'zelfredzaaamheid'. Als voorbeeld neem ik de in 1992 verschenen nota Verpleeghuizen op de zorgmarkt van de Nederlandse Vereniging voor Verpleeghuiszorg (NVVZ). In deze nota wordt het 'basale uitgangspunt' van de verpleeghuiszorg omschreven als : 'Het (samen met anderen) creëren van omstandigheden, waardoor hulpbehoevende ouderen in de gelegenheid zijn zo lang mogelijk in meerdere of mindere mate zelfstandig te blijven.' Volgens de nota wordt het zelfbeschikkingsrecht van iedere persoon niet alleen gerespecteerd, maar ook tot basismotivatie voor de hulpverlening gemaakt.

Terwijl in deze nota de term autonomie nog niet wordt genoemd, komt deze term expliciet naar voren in de in 1993 verschenen driedelige NVVZ nota Kwaliteitskenmerken verpleeghuiszorg. In deze nota wordt gesteld dat verpleeghuiszorg méér moet zijn dan alleen het aanbieden van noodzakelijke zorg. Zij moet ook gericht zijn op het terugdringen, stabiliseren of opheffen van de zorgbehoefte. ${ }^{2}$ In hun bejegening van en communicatie met de cliënt dienen de zorgverleners zoveel mogelijk rekening te houden met diens keuzen, opdat zij of hij ondanks de afhankelijkheid zoveel mogelijk haar of zijn leven kan leiden. Autonomie wordt daarbij geformuleerd als 'medezeggenschap' en 'recht op zelfbeschikking', hetgeen er op neerkomt dat het 'cliëntsysteem' (cliënt en/of vertegenwoordiger) nadrukkelijk wordt gevraagd om zijn toestemming voor allerlei zaken betreffende opname, zorgplan, behandeling en verblijf, en eventueel ontslag. Het respect voor de eigen keuzen van de cliënt 
alsmede het waarborgen van diens zelfstandigheid zijn natuurlijk belangrijke en lovenswaardige uitgangspunten voor de zorg voor hulpbehoevende ouderen, in het bijzonder de verpleeghuiszorg. Aldus wordt verzekerd dat andere mensen, vanuit een al dan niet welgemeende bemoeizucht, invulling gaan geven aan ons eigen leven. In die zin is het recht op zelfbeschikking een noodzakelijke voorwaarde voor de eigen autonomie. De vraag is echter of het ook een voldoende voorwaarde vormt. Als ons de vrijheid wordt geboden zelf aan ons leven invulling te geven, hebben we dan niet meer nodig dan alleen een formeel recht op zelfbeschikking?

\section{Autonomie als negatieve vrijheid}

In dit verband wil ik ingaan op de opvattingen van de amerikaanse fenomenologische auteur George Agich, zoals neergelegd in zijn boek Autonomy and Long-Term Care dat vorig jaar verscheen. Volgens Agich wordt in de theorievorming over autonomie, met name in het anglo-saxische taalgebied, dit begrip uitsluitend uitgelegd als vrijheid tot het maken van keuzen en het volgen van eigen preferenties. ${ }^{3}$ Vrijheid wordt daarbij vooral negatief gedefinieerd, dat wil zeggen in de zin van 'niet gehinderd door anderen'. Volgens Agich stamt dit negatieve vrijheidsideaal uit de politieke sfeer waar het vooral is bedoeld om individuen te vrijwaren van interventies van de staat in hun persoonlijke en zakelijke belangen.

Wat betreft de relaties tussen de individuen onderling, in het bijzonder de zorg voor hulpbehoevende ouderen, schiet deze liberale ideologie tekort. Het liberalisme heeft belangrijke verworvenheden opgeleverd als het gaat om de bescherming van de lichamelijke en geestelijke integriteit van individuen. Zo zijn het recht op informatie, het principe van de vrije toestemming en het waarborgen van de privacy belangrijke en niet meer weg te denken ethische beginselen in de gezondheidszorg, ook in de zorg voor chronisch zieke ouderen. Toch zouden de relaties tussen individuen ernstig verschralen, wanneer zij louter in deze termen zouden worden geïnterpreteerd. Zo stelde Henk Manschot in zijn oratie, dat wezenlijke aspecten van de relatie tussen arts en patiënt of tussen verzorger en verzorgde geblokkeerd raken, wanneer deze relatie wordt geënt op omgangsregels die gelden tussen burgers in het liberale model. 4 
Agich wijst op discussies in de amerikaanse psychiatrie, waar volgens sommigen het recht op zelfbeschikking is ontaard in 'a right to rot'. ${ }^{5}$ Het vrijheidsideaal wordt daar zo radicaal uitgelegd dat individuen 'met rust gelaten worden', zelfs als hun feitelijke toestand directe interventies noodzakelijk maakt. Nu is de situatie in de nederlandse gezondheidszorg bij lange na niet te vergelijken met die in de Verenigde Staten, waar de opmars van het recht de relatie tussen hulpverleners en patiënten ernstig heeft ontwricht. Bevreesd voor een rechtszaak wegens 'malpractice', nemen artsen en andere hulpverleners een uiterst defensieve houding aan en beperken zich tot het strikt noodzakelijke, en alleen wanneer de patiënt daar expliciet zijn toestemming voor heeft gegeven. Toch zijn waarschuwingen voor een vergelijkbare ontwikkeling in Nederland op zijn plaats. Zo is er in de psychiatrie in ons land al geruime tijd sprake van een ontwikkeling waarbij juridische regels, in het bijzonder rond de zelfbeschikking van de cliënt, de relatie tussen cliënt en hulpverlener zijn gaan bepalen. ${ }^{6}$ Hoewel deze zogenaamde juridisering belangrijke humanistische en vrijheidswaarborgende effecten heeft gehad, heeft zij in de psychiatrie geleid tot aanzienlijke frustraties bij hulpverleners. Legemaate wijst er op dat ook in andere sectoren van de gezondheidszorg deze juridisering waarneembaar is. ${ }^{7}$ Daarbij moet men niet denken aan een toenemend aantal schadeclaims bij de rechter, maar vooral ook aan de formalisering van de hulpverlening vanuit het oogpunt van de bescherming van de autonomie van de patiënt.

Wat betreft de zorg voor hulpbehoevende ouderen kan hier onder meer gewezen worden op de transitie van verpleeghuis naar de thuissituatie. Hoewel de autonomie in de zin van zelfstandigheid van ouderen hiermee wordt vergroot, wordt nu al gesproken over een toenemend gevaar van eenzaamheid en van een 'zwart gat' waarin ouderen thuis terecht kunnen komen. Eenzaamheid wordt wel eens de grootste kwaal van onze tijd genoemd. Dit probleem dreigt ook in de verpleeghuizen zelf: door schaarste aan middelen en personeel en daarmee toenemende werkdruk komt men vaak niet verder dan strikt 'noodzakelijke zorg', dat wil zeggen het regime van 'sleeping and feeding'. De zorg voor de autonomie schiet daarbij al snel tekort, zelfs in zijn strikt politiek-liberale betekenis: de regels van het huis gaan voor de keuzen van de cliënt. 


\section{Het begrip persoon}

De juridische benadering van autonomie als negatieve vrijheid vindt zijn pendant in de 'mainstream' van de gezondheidsethiek, waarin aan het respect voor de autonomie een belangrijke en soms overheersende waarde wordt toegekend. In het boek Ethiek in de praktijk, samengesteld door medewerkers van het Utrechtse Centrum voor Bio-ethiek en Gezondheidsrecht, wordt deze autonomie omschreven als de mogelijkheid om 'over jezelf te beschikken', dat wil zeggen 'zelf te bepalen hoe je leven er uit ziet, zelf te kiezen, zelf de richting aan te geven van je handelen'. 8 Respect voor autonomie, aldus de auteurs, 'betekent dus respect voor deze zelfbeschikking; respect voor de keuzen die de mensen zelf maken ten aanzien van hun eigen leven en levensinrichting'.9 Door de eigen wil te respecteren, zo gaat men verder, wordt uitdrukking gegeven aan de eigenheid en uniciteit van iedere mens.

Het respect voor autonomie, in de zin van vrije zelfbeschikking, wordt in de gezondheidsethiek filosofisch gefundeerd op het begrip van de persoon. De persoon wordt opgevat als een rationeel, zelfbewust wezen dat op autonome wijze richting weet te geven aan het eigen leven. 10 Aan het persoon-zijn zijn bepaalde rechten en plichten verbonden, onder meer het respect voor de beslissingen die door de persoon worden genomen.

De term persoon stamt af van het Latijnse woord 'persona' dat wortels heeft in het Etruskische woord 'phersu'. Met deze term werd aan-vankelijk gedoeld op het masker van de toneelspeler en daarmee op de rol die deze vervulde in het toneelstuk. In de Romeinse wereld ging de term persoon duiden op de maatschappelijke rol van individuen met alle rechten en plichten die daaraan zijn verbonden.

De term persoon ging later een rol spelen in de vroeg-christelijke filosofie, in het bijzonder in het daarin beleden substantialistische denken. Volgens het substantialisme moet de werkelijkheid worden geinterpreteerd als bestaande uit onafhankelijke en onveranderlijke zelfstandigheden, ook wel substanties genoemd. Een belangrijke vertegenwoordiger van deze filosofie was Boëthius volgens wie de term persoon alleen kon gelden voor substanties met een rationele natuur. Zulke substanties, aldus Boëtius bestaan altijd als indivi- 
duen. Aldus kwam hij tot de definitie van de persoon als 'naturae rationalis individua substantia' ('De persoon is een substantie van individuele en rationele aard'). Zulke personen zijn God, de engelen en mensen. In de scholastieke filosofie werd dit begrip van de persoon verder uitgewerkt. Zo ging ook Thomas van Aquino uit van de persoon als een individuele, immateriële substantie van rationele aard. 11

In de gezondheidsethiek, en met name in die stromingen die een seculier antwoord willen geven op morele problemen, wordt vooral teruggegrepen naar het persoonsbegrip van Immanuël Kant. Volgens Kant is de mens een persoon, omdat hij ondanks alle veranderingen die hij ondergaat zich steeds als een onveranderlijke eenheid ervaart. Deze eenheid is niet het produkt van een substantie buiten het subject, maar is het produkt van het denken zelf. Substantie, aldus Kant is een categorie waarmee het subjekt zijn ervaring construeert. Deze categorie kan dan ook niet aan het denken zelf ten grondslag worden gelegd.

De persoon is volgens Kant niet alleen ondeelbaar en identiek, hij is ook een vrij wezen. De mens kan zijn eigen handelen bepalen, onafhankelijk van de wetmatigheden in de natuurlijke omgeving of van zijn eigen lichaam. Vrijheid wordt daarbij door Kant gezien als het volgen van de plicht. Dit betekent dat men moet handelen volgens voorschriften die voor iedereen onvoorwaardelijk en te allen tijde bindend zijn (categorische imperatief). Door de rede komt de persoon tot het inzicht wat de voornaamste plicht is van zijn handelen. De vrijheid van de persoon vormt voor Kant de grondslag van het morele handelen. Als zodanig dient deze vrijheid of autonomie door iedereen te worden gerespecteerd. Wanneer de vrijheid van de persoon niet wordt gerespecteerd, blokkeert men de mogelijkheid tot moreel handelen.

\section{Persoon en onderhandelingshuishouding}

In navolging van Kant wordt in de gezondheidsethiek de persoon gezien als een individueel en rationeel wezen wiens autonome beslissingen in de regel dienen te worden gerespecteerd. Terwijl de vrijheid van de persoon door Kant wordt gezien als een gehoorzamen aan de plicht, wordt in de gezondheidsethiek de vrijheid 
louter gezien als vrijheid om te beschikken over eigen lijf en leden, zonder enige referentie naar een universele, categorische plicht. De enige grens die aan de vrijheid wordt gesteld is de vrijheid of autonomie van de ander. Dat wil zeggen dat de keuzen die men makt niet mogen leiden tot een onaanvaardbare inperking van de keuzevrijheid van een ander. Hub Zwart stelt in zijn dissertatie terecht, dat de ethiek van Kant en de daarin opgenomen idee van de vrijheid is gevulgariseerd tot een sociale ethiek, die sterk is 'angehaucht' door het liberalisme van Mill.12

Met deze op een mengeling van Kant èn Mill gefundeerde sociale ethiek, sluit de gezondheidsethiek nauw aan bij het zelfbeeld van het individu in de moderne, burgerlijke cultuur, waarin vrijheid, individualiteit en rationaliteit centraal zijn komen te staan. Dit zelfbeeld kan worden gezien als een ideologisch construct, dat wil zeggen dat het een juiste en tegelijkertijd onjuiste afspiegeling is van de maatschappelijke werkelijkheid. ${ }^{13}$

Het dominante persoonsbegrip is juist in zoverre van individuen wordt verwacht dat zij zelfbewust, rationeel en met wederzijds respect met elkaar omgaan en daarbij duidelijk aangeven wat zij verlangen. Geweld of autoritaire bevelen dienen daarbij te worden geschuwd: onderlinge geschillen dienen door argumenten en overleg te worden beslecht. Abram de Swaan heeft in zijn oratie in 1979 deze onderlinge omgang gekarakteriseerd met de term onderhandelingshuishouding. 14 Volgens De Swaan is deze vorm van gevoelshuishouding in de plaats gekomen van de bevelshuishouding die in de laatste 100 jaar geleidelijk uit onze samenleving is verdwenen. Ten gevolge van dit proces is er in de samenleving een grotere ruimte ontstaan voor omgangs- en uitingsvormen en zijn er minder geboden ten aanzien van de inhoud van de onderlinge relaties. Tegelijkertijd is deze verruiming en liberalisering gepaard gegaan met rieuwe beperkingen. Deze schrijven niet zozeer voor welke relaties zijn toegestaan als wel de manier waarop individuen deze verhoudingen dienen te regelen. In het maatschappelijk verkeer is volgens De Swaan de bewegingsruimte toegenomen, 'maar onder de beperkende voorwaarde dat de betrokkenen hun omgang regelen in onderling overleg en naar wederzijdse toestemming'.15 Terwijl de inhoud van de relaties is geliberaliseerd, is de vorm aan strenge regels onderworpen. 
De opkomst van de onderhandelingshuishouding vormt de achtergrond van de toegenomen nadruk in de gezondheidsethiek op het beginsel van de 'free and informed consent': artsen dienen de wensen van de patiënt te respecteren en door middel van onderhandeling tot een overeenkomst te komen over de te volgen behandeling. De patiënt dient duidelijk te weten wat hij wil en dient deze verlangens zo goed mogelijk kenbaar te maken naar de behandelend arts. In plaats van de traditionele gezagsverhouding is de relatie tussen arts en patiënt momenteel gebaseerd op onderhandeling en onderling overleg.

In de gezondheidsethiek wordt deze onderhandelingsmoraal het meest pregnant tot uitdrukking gebracht door H.T. Engelhardt. Volgens deze texaanse arts en filosoof zijn er in onze cultuur geen inhoudelijke morele waarheden meer te vinden die door de individuen gezamenlijk worden onderschreven: God en de Rede hebben afgedaan als universele uitgangspunten voor het morele handelen. ${ }^{16}$ De samenleving is opgedeeld in een pluraliteit van kleine morele gemeenschappen waarbinnen de individuen een inhoudelijke moraal delen. Buiten deze 'moral communities' treden de individuen elkaar tegemoet als 'moral strangers' dat wil zeggen als individuen die met elkaar geen inhoudelijke moraal delen. Om te voorkomen dat morele verschillen in de samenleving door geweld worden opgelost, dienen de individuen in hun wederzijdse contacten zich te baseren op het formele principe van de vrije, geïnformeerde toestemming.

Engelhardt's begrip van de persoon staat in direct verband met zijn opvattingen over de morele pluriformiteit van de moderne samenleving. Individuen zijn een persoon, voor zover zij argumenten kunnen geven voor hun verlangens en op redelijk wijze met andere individuen daarover kunnen onderhandelen: 'To be a person is to be a possible negotiator'. 17 Redelijk moet daarbij overigens niet zozeer worden opgevat als redelijk of rationeel in formeel-logische zin. Redelijk wil hier zeggen dat men op begrijpelijke wijze rekenschap kan geven voor de eigen gevoelens en gedachten en dat men argumenten kan geven voor het eigen standpunt. 


\section{Naar een sociaal begrip van de persoon}

Het individualistische en rationalistische persoonsbegrip is in maatschappelijk opzicht juist, omdat in onze moderne cultuur inderdaad van personen wordt verwacht dat zij op redelijke wijze met elkaar onderhandelen. Het persoonsbegrip van Engelhardt is in maatschappelijk opzicht onjuist omdat het voorbijgaat aan de sociale processen die aan het appèl tot onderhandeling ten grondslag liggen. Dit morele appèl hangt ten nauwste samen met de toenemende sociale vervlechting binnen de moderne staat. In plaats van de afhankelijkheid van de kleine, gesloten groep zijn de individuen steeds meer door andere afhankelijkheidsrelaties aaneengeschakeld. 18 In dit ontvouwingsproces, dat voor het eerst door Norbert Elias werd beschreven, 19 heeft de dwang van bovenaf, ofwel de 'Fremdzwang', plaatsgemaakt voor zelfbeheersing ofwel 'Selbstzwang' (idem) waarbij individuen op subtiele wijze aan hun maatschappelijke taken werden gebonden. Door deze gevoelsbeheersing is volgens Elias het moderne individu zichzelf gaan ervaren als een afgesloten ' $\mathrm{ik}$ ', een homo clausus, die zich gescheiden en onafhankelijk ervaart van de medemens. 20 Deze opvatting van de absoluut onafhankelijk van elkaar beslissende en handelende afzonderlijke mensen is volgens Elias echter een fictie, een 'kunstproduct van het menselijk denken dat karakteristiek is voor een bepaald niveau in de ontwikkeling van hun zelfervaring' .21 In plaats van de mens als een 'gesloten persoonlijkheid', moeten we hem zien als een 'open persoonlijkheid', dat wil zeggen als een persoonlijkheid 'die in zijn verhouding tot andere mensen een hogere of geringere graad van autonomie, maar nooit absolute of totale autonomie bezit, die inderdaad tijdens zijn leven fundamenteel op andere mensen is afgestemd en aangewezen, van andere mensen afhankelijk is'.22

In Engelhardt's definitie van de persoon c.q. van de autonomie worden deze sociale determinaties niet of nauwelijks tot begrip gebracht. Ditzelfde geldt voor de meerderheid van andere gezondheidsethici. ${ }^{23}$ In de definities van de persoon concentreert men zich op eigenschappen als redelijkheid, individualiteit en zelfbeschikking en gaat men voorbij aan de sociale structuren waarbinnen deze eigenschappen een rol spelen. ${ }^{24}$ 
Vanuit andere theoretische optieken, buiten de figuratiesociologie van Elias en De Swaan, is eveneens kritiek geleverd op de eenzijdige nadruk op zelfbeschikking en de miskenning van de sociale relaties waarin deze zelfbeschikking figureert of wordt geconstitueerd. ${ }^{25} \mathrm{lk}$ noem hier onder andere het structuralisme waarin word gesteld dat de mens in wezen verdeeld is, opgenomen is in verscheidene onzichtbare structuren die zijn handelen bepalen. Als de mens zich als een eenheid ervaart of als een zelfbewust oorspronkelijk handelend wezen dan is dat volgens het structuralisme een effect van de werking van de onbewuste structuur. Ik verwijs hier naar de structuralistische psychoanalyse van Jacques Lacan, ${ }^{26}$ maar ook naar het werk van Michel Foucault. Volgens Foucault wordt macht niet meer openbaar uitgeoefend, zoals ten tijde van de absolute staat, maar via een onzichtbaar netwerk van praktijken en wetenschappelijke disciplines, in het bijzonder de geneeskunde. 27 De opkomst van deze machtspraktijken is gepaard gegaan met een humanistische ideologie waarin vrijheid en zelfbeschikking centraal staan.

Vanuit het standpunt van de cultuurkritiek kan het 'a-sociale' persoonsbegrip eveneens worden bekritiseerd. Auteurs als Christopher Lasch, Robert Bellah en Charles Taylor wijzen op de toenemende onderlinge vervreemding in de moderne cultuur: de gemeenschapszin en het opkomen voor de ander (solidariteit) hebben plaats gemaakt voor een ongebreideld individualisme en egoïsme. ${ }^{28}$ De publieke moraal is volgens deze critici uiteen gevallen: ieder individu jaagt op zijn eigen belangen en heeft een persoonlijke standaard van goed en kwaad. ${ }^{29}$ Deze kritiek kreeg einde jaren '70 met name vorm in het werk van Lasch. Volgens Lasch is in de moderne cultuur sprake van een sterke opkomst van het narcistische persoonlijkheidstype, voor wie de wereld slechts een spiegel is van het eigen 'grandioze zelf'. De narcistische nadruk op de eigen individualiteit is ten koste gegaan van de verbondenheid met de groep met alle psychologische en psychiatrische gevolgen vandien. Zo stelt Cushman, dat in de naoorlogse samenleving het individu steeds meer geconfronteerd werd met de afwezigheid van gemeenschapsbanden en met gedeelde zingevingssystemen. Dit gebrek aan verbondenheid heeft geleid tot een innerlijke leegte, door Cushman aangeduid als 'empty self'. Deze innerlijke leegte proberen de individuen (tevergeefs) te vullen door de consumptie van materiële goederen. 30 
De concentratie op het (narcistische) individu heeft geleid tot een verregaande fragmentering van de moraal, waarbij het individuele gevoel maatgevend is geworden voor goed en kwaad. 31 Het probleem van het pluralisme in de ethiek en de (on)mogelijkheid te komen tot een ethische consensus hangt nauw samen met de onmogelijkheid van het narcistische individu om buiten zichzelf een maatstaf te vinden voor het morele handelen.

Deze cultuurkritiek is overigens niet in tegenspraak met de hierboven beschreven analyse van de moderne onderhandelingscultuur. Het door Elias en De Swaan beschreven ontvouwingsproces heeft enerzijds geleid tot een aaneenschakeling van de individuen door wijdvertakte afhankelijkheidsrelaties van de moderne verzorgingsstaat, maar heeft anderzijds de individuen ook teruggeworpen op de eigen gevoelens. De differentiatie van de onderlinge afhankelijkheid gaat aldus samen met een gevoel van vereenzaming en een gemis aan levensbeschouwelijke en morele kaders. De huidige mens is, zoals reeds gemeld, een homo clausus, weliswaar zelfstandig en onafhankelijk, maar tegelijk in zijn zelfervaring afgesloten van anderen. 32

In het licht van sociologische analyses en cultuurkritische beschouwingen behoeft het persoonsbegrip in de gezondheidsethiek een belangrijke correctie. De nadruk op de autonome individualiteit met al zijn morele consequenties vandien, zal moeten worden bijgesteld in de richting van een sociaal of relationeel persoonsbegrip, waarbij aandacht wordt besteed aan de sociale context waarin de persoon tot ontwikkeling komt. 33

\section{Personaliteit en identiteit}

In zijn studie over autonomie en de zorg voor chronisch zieken houdt Agich eveneens een pleidooi voor een sociaal begrip van de persoon, c.q. van de autonomie. Volgens Agich is de visie op de persoon als een rationeel en vrij individu een abstractie van de werkelijkheid. In hun feitelijke handelen laten individuen zich minder leiden door expliciet rationele besluiten als wel door het beeld dat zij hebben van zichzelf. Autonoom handelen betekent in de praktijk, dat je handelen voortvloeit uit en consistent is met je eigen identiteit. ${ }^{34}$ Deze vorm van autonomie noemt Agich 'actual 
autonomy', dat wil zeggen feitelijke autonomie. Zij onderscheidt zich van de 'ideal autonomy', doordat zij autonomie niet ziet in termen van een abstract, rationeel zelf, maar meer kijkt naar de manier waarop individuen in de werkelijkheid hun autonomie ervaren.

- Het aspect van de identificatie of herkenning speelt hierbij een belangrijke rol. Hoe meer ik mij herken in of identificeer met bepaalde handelingen of producten, des te autonomer voel ik mij. Wanneer ik een artikel schrijf of deze oratie en ik kan mij daarmee identificeren, dan gaat dat gepaard met een gevoel van autonomie. Dit gevoel kan ook optreden tijdens de activiteit zelf: hoe meer ik mij in een activiteit kan verliezen, des te meer ervaar ik een gevoel van autonomie. Dit fenomeen is al eerder beschreven door Scheler en Buytendijk met de term deemoed: door zich volledig en liefdevol over te geven aan de omgeving, zal het subject een steeds grotere vrijheid en autonomie gaan ervaren met als gevolg een toename van de persoonlijke groei en een versterking van het zelfbewustzijn. 35

Volgens Agich is autonomie in deze zin nooit 'af': het individu ontwikkelt zich voortdurend en wordt daarbij gevoed door allerlei ervaringen en sociale interacties. Terwijl de abstracte autonomieopvatting uitgaat van de persoon als een voltooid wezen, gaat de feitelijke autonomie opvatting uit van de persoon als een dynamisch en zich ontwikkelend geheel. Autonomie is in deze opvatting dan ook geen eindtoestand, maar een proces, waarin de persoon tot zichzelf komt. Autonoom zijn wil zeggen, ontwikkeling van het zelf, niet volgens een abstrakt ideaal, maar door een identificatie met de zich voortdurende wijzigende omstandigheden.

In de zorg voor chronisch zieke ouderen dient dit proces zo goed mogelijk te worden ondersteund. Dit betekent dat de zorg zodanig moet worden ingericht, dat de oudere zichzelf weer kan herkennen in zijn eigen handelen. Respect voor autonomie is dan ook nie beperkt tot dramatische medische beslissingen, bijvoorbeeld ove wel of niet behandelen aan het einde van het leven, maar is eel proces dat zich voortdurend in de dagelijkse zorg afspeelt. He betekent onder meer dat individuen in een verpleeghuis de ruimt krijgen voor het maken van betekenisvolle keuzen, met name wa betreft de dagelijkse gang van zaken. Rosalie Kane en Arthur Caplaı 
spreken in dit verband over de 'everyday ethics': juist in de gewone dagelijkse omgang en verzorging liggen allerlei mogelijkheden èn blokkades voor de ontplooiing van de autonomie. ${ }^{36}$ Dat kan variëren van eigen keuzen wat betreft de eet- en slaaptijden tot de inrichting van de kamer of het dragen van bepaalde kleding. Voor de goede orde is in elk verpleeghuis een bepaald regime nodig, maar dat regime zal niet ten koste mogen gaan van een sociale sfeer waarin individuen zich kunnen herkennen en waarin zij hun eigen individualiteit kunnen ontplooien.

\section{Autonomie en afhankelijkheid}

De vraag doet zich voor of autonomie en gebrekkigheid ten gevolge van chronische ziekte zich überhaupt wel met elkaar laten verbinden. Het krijgen van een chronische aandoening betekent in veel gevallen een dramatische inbreuk in het leven van de betrokkenen. Levensplannen worden, soms abrupt, afgebroken, sociale relaties worden verstoord en alledaagse activiteiten worden ernstig belemmerd. De drastische veranderingen in het lichaam hebben bovenal ernstige consequenties voor de beleving van het eigen zelf. De sociologe Kathy Charmaz spreekt in dit verband over een 'constant struggle': mensen met een ernstige langdurige of blijvende aandoening moeten voortdurend vechten voor hun eigen identiteit, tegen alle gebreken, pijn en eenzaamheid in. 37 De zorg voor de autonomie staat dan ook geenszins haaks op de afhankelijkheid van de chronisch zieke. Integendeel, juist in het licht van zijn chronische ziekte heeft de hulpbehoevende oudere behoefte aan steun bij het terugvinden en aanpassen van zijn identiteit. Juist dan moet zij of hij zich kunnen herkennen in de keuzes die zij of hij maakt en moeten er mogelijkheden worden geboden om deze keuzes inderdaad te maken. Juist dan is het belangrijk om in relatie met hulpverleners en anderen de eigen identiteit terug te winnen of te vernieuwen.

In dit proces is de betrokkenheid van anderen, in het bijzonder van de hulpverlener van groot belang. Autonomie als ontwikkeling van de eigen identiteit is een relationeel proces. Het vereist onder meer, zoals Paul Sporken het stelt, 'dat men de ander onvoorwaardelijk ernstig neemt,....dat men bereid is diens authentieke belangen als norm van de zorg te beschouwen'. ${ }^{38}$ Sporken legt hier een groot 
gewicht bij de authentieke en werkelijke belangen van de hulpvrager: het gevaar is immers niet denkbeeldig dat de hulpverlener, alle goede bedoelingen ten spijt, zijn eigen visies tot norm van de hulpverlening maakt. Dan zou de hulpvrager een identiteit worden opgedrongen die hem vreemd is (want van de hulpverlener). ${ }^{39}$

Deze 'ethisch verantwoorde attitude' (Sporken) vinden we ook terug in de opkomende 'ethics of care' ofwel zorgethiek, zoals die onder meer door Joan Tronto wordt geformuleerd. 40 Tronto gaat ervan uit, dat de mens gedurende zijn leven verschillende periodes doormaakt van afhankelijkheid en onafhankelijkheid, van gebrekkigheid en autonomie. ${ }^{41}$ Juist in de zorg moeten wij rekening houden met de kwetsbaarheid en afhankelijkheid van de hulpbehoevende ander. Een essentiële kwaliteit van de zorg is volgens Tronto de verantwoordelijkheid, in de zin van inzet voor en betrokkenheid met de ander. Daarnaast noemt zij competentie, attentiviteit en open-staanvoor-de-ander ('responsiveness'). Wat betreft dit laatste stelt zij dat de zorg, met inbegrip van de zorg voor de autonomie, geen eenrichtingsverkeer mag en kan zijn vanuit de hulpverlener, maar dat hier ook de inzet en medewerking van de hulpvrager een vereiste is.

\section{De betekenis van de ouderdom}

De betrokkenheid van de hulpverlener is een noodzakelijke, maar geen voldoende voorwaarde voor het herwinnen of behouden van de autonomie bij chronische ziekte. Nodig is ook een levensbeschouwelijk kader waarbinnen de afhankelijkheid kan worden geïnterpreteerd. Een belangrijk probleem is hier dat wij in onze moderne samenleving geen betekenis meer geven of weten te geven aan ouderdom en gebrekkigheid. We leven steeds meer in een leeftijdsloze samenleving, waarin de eeuwige jeugd als zaligmakende norm wordt gepropageerd. Aan de ene kant zien we een vroeg volwassen jeugd en aan de andere kant zien we een tendens om de zo lang mogelijk een jong volwassene te blijven, middels kleding, muziek en andere uitingen. 42 Volgens Van Meel wordt momenteel op grote schaal geprobeerd de wetten van de levensfase naar de eigen hand te zetten: 'De rebellie tegen de consequenties van het leeftijdsverloop heeft massale vormen aangenomen.'43 
Deze ontwikkeling hangt nauw samen met de opkomst van de onderhandelingshuishouding, zoals hierboven aangehaald. In een samenleving die op onderhandelingsprocessen is gebaseerd is er geen norm of een vast punt waarop men zich kan richten. Er zijn alleen regels voor omgang met elkaar, niet voor de inhoud. De enige zekerheid die je hebt ligt in jezelf, in de eigen gevoelens. Juist die speurtocht naar het zelf en de daarmee gepaard gaande verabsolutering van het 'ik', breekt oude omheiningen af, met name die van leeftijd en generatie. Tradities gelden daarbij niet meer als richtsnoer voor het handelen, maar belemmeren in feite de zoektocht naar het 'eigen zelf'. ${ }^{44}$

In deze jeugdige samenleving lijkt ouderdom niet meer te bestaan als aparte fase met een eigen specifieke betekenis. Terwijl in vroeger tijden veroudering werd gezien als een existentieel proces met lichamelijke en geestelijke aspecten, wordt in de moderne tijd ouderdom gezien als een praktisch probleem, dat met behulp van research en techniek kan worden opgelost. ${ }^{45} \mathrm{Ik}$ wijs hier op de verwoede pogingen om de genetische oorzaken van veroudering op te sporen. Een zelfde tendens zien we in de sociale wetenschappen, waar gerontologen het ideaal van 'active ageing' uitdragen.

Natuurlijk is er niets op tegen om zo lang mogelijk jong en actief te blijven. Het is eveneens uitermate belangrijk dat ouderen gelijkwaardig worden behandeld in onze samenleving en niet om hun 'ouder-zijn' worden gediscrimineerd. 46 Toch moeten we ons realiseren dat we ééns aan ons einde komen, alle pogingen tot verjonging ten spijt. We moeten ons ook realiseren dat dit einde niet zelden vooraf gegaan wordt door een langdurige periode van ziekte en handicap. Omdat wij onze zinnen hebben gezet op jeugdigheid en activiteit, weten wij aan deze gebrekkigheid geen betekenis meer te geven. Toch is de aanvaarding en integratie van deze gebrekkigheid, zoals Henk Manschot terecht stelt, een belangrijke voorwaarde voor het realiseren van onze autonomie. 47

In dit verband wijs ik gaarne op wat Charles Taylor de "horizon of meaning' heeft genoemd. 48 Volgens Taylor kunnen wij onze identiteit alleen ontwikkelen wanneer wij ons verbonden voelen met een groter geheel, dat wil zeggen met een bepaalde spirituele of culturele traditie. De liberalisering van onze cultuur heeft weliswaar 
bepaalde politieke rechten met zich meegebracht, maar heeft ook de betekenishorizon doen verdwijnen. De mens is zich daarbij steeds meer als een zichzelf bepalend wezen gaan ervaren. De prijs voor deze vrijheid is een gevoel van zinloosheid en trivialiteit van het bestaan. Wat nodig is, aldus Taylor, is een 'art of retrieval', dat wil zeggen een poging tot terugwinnen van verloren gegane betekenissen, in casu de betekenis van de ouderdom. Een dergelijke betekenishorizon is constitutief voor onze identiteit en is een noodzakelijke voorwaarde voor de ontplooiing van onze autonomie. ${ }^{49}$

Door het terugvinden van een gemeenschappelijk gedeelde horizon van betekenis kunnen de onderlinge banden groeien en kan tegenwicht worden geboden tegen de fragmentering van de samenleving in losse individuen. In het bijzonder vormt een gemeenschappelijk gedeelde betekenis van ouderdom en gebrekkigheid een onmisbare voorwaarde ter voorkoming van een oprukkende individualisering en daarmee dreigende verschraling van de zorg voor hulpbehoevende ouderen: Levensbeschouwelijke kaders zijn dan ook geen vorm van luxe, maar een noodzakelijke aanvulling op een eenzijdige politiek-liberale versmalling van het begrip autonomie.

\section{Geachte toehoorders}

Aan het einde gekomen van mijn betoog wil ik gaarne enkele woorden van dank uitspreken.

Allereerst dank ik het Bestuur van de Radboudstichting Wetenschappelijk Onderwijsfonds voor het in mij gestelde vertrouwen. Ik dank ook het Bestuur van de Stichting Instituut voor Gezondheidsethiek voor zijn bereidheid mij voor een deel van mijn werktijd te detacheren bij de Radboudstichting.

Voorts dank ik al degenen die mij gedurende mijn wetenschappelijke loopbaan hebben gevormd. Enkele van hen wil ik hier speciaal noemen. Allereerst Gerlof Verwey, mijn leermeester in het ontdekken en systematiseren van anthropologische vooronderstellingen in het wetenschappelijk denken en handelen. Ik dank jou Gerlof in het bijzonder voor de belangeloze interesse waarmee je mijn latere wetenschappelijke werk bent blijven volgen, ook al heb ik mij 
moeten verwijderen van ons gezamenlijke werkveld, de geschiedenis van de psychologie en de psychiatrie. Ik dank verder Kees Struyker Boudier die als promotor mij wegwijs heeft gemaakt in het rijk geschakeerde katholieke geestesleven. Ik dank ook Willem Berger voor zijn inspirerende inzichten wat betreft de relatie tussen culturele processen en zingevingsvraagstukken. Maurice de Wachter dank ik voor zijn goede raad bij mijn eerste schreden door de gezondheidsethiek.

Ik dank mijn collega's op de Vakgroep Gezondheidsethiek en Wijsbegeerte voor hun hartelijke en warme ontvangst. Speciaal Rob Houtepen voor zijn waardevolle adviezen wat betreft de integratie van mijn onderwijstaken in het Maastrichtse onderwijs en Guy Widdershoven voor zijn steun bij het opzetten van een onderwijs- en onderzoeksstructuur op het gebied van de ethiek binnen de vakgroep. Ik dank de studenten voor de interesse en het enthousiasme waarmee zij tot nu toe mijn onderwijs hebben gevolgd.

Ik dank ook mijn collega's op het Instituut voor Gezondheidsthiek, in het bijzonder Ron Berghmans en Ireen Proot voor hun welkome en waardevolle suggesties bij het samenstellen van deze rede.

Tenslotte het thuisfront. Hanna en Simon, dank je wel voor jullie geduld, vooral voor het aanhoren van deze lange les. Hetty, zonder jouw steun en inzicht had ik op deze plaats nooit gestaan.

Ik dank $U$ allen voor Uw aandacht. 
Verschraalde zorg? 


\section{Noten}

1.Nederlandse Vereniging voor Verpleeghuiszorg, Verpleeghuizen op de zorgmarkt. Een handreiking voor een inhoudelijke plaatsbepaling, Utrecht 1992, p. 13.

2.Nederlandse Vereniging voor Verpleeghuiszorg, Kwaliteitskenmerken verpleeghuiszorg. Deel II. Handleiding, Utrecht 1993, p.9.

3.G. Agich, Autonomy and Long-Term Care, New York 1993, p.8.

4. H. Manschot, Levenskunst of lijfsbehoud? Een humanistische kritiek op het beginsel van autonomie in de gezondheidszorg. Inaugurele Rede Universiteit voor Humanistiek, Utrecht 1992, p.12.

5.G. Agich, o.c., p. 22.

6. J. Legemaate, Goed recht. De betekenis en de gevolgen van het recht voor de praktijk van de hulpverlening. Praeadvies uitgebracht ten behoeve van de jaarvergadering van de Vereniging voor Gezondheidsrecht op 22 april 1994, Maarssen 1994.

7. J. Legemaate, o.c. p.13.

8.T. van Willigenburg, A. van den Beld, F.R. Heeger \& M.F. Verweij, Ethiek in praktijk, Assen 1993, p. 39.

9. idem.

10. Een uitgebreid overzicht over het begrip persoon en de betekenis daarvan in de gezondheidsethiek vindt men in de bundel Persona. Het persoonsbegrip en de bio-ethiek, samengesteld en onder redactie van M.A.M. de Wachter uitgegeven door het Instituut voor Gezondheidsethiek te Maastricht (1994).

11. McCartney, J.J., Unborn persons. Pdpe John Paul II and the Abortion Debate, New York 1987.

12. H. Zwart, Ethische consensus in een pluralistische samenleving. De gezondheidsethiek als casus. Amsterdam 1993.

13. J. Larrain, The Concept of Ideology, London 1979.

14. Swaan, A. de, 'Uitgaansbeperking en uitgangsangst. Over de verschuiving van bevelshuishouding naar onderhandelings huishouding'. In: De Gids, 140 (8) (1979), p. 483-509.

15. De Swaan, o.c., p. 493.

16. H.T. Engelhardt Jr., The Foundations of Bioethics, New York 1986.

17.H.T. Engelhardt Jr., 'Foundations, Persons and the Battle for the Millennium', In: Journal of Medicine and Philosophy, 13 (1988), p. 387-39l. (Italics, RtM) 
18. N. Elias, Sociologie en geschiedenis en andere essays, Amsterdam 1971.

19.N. Elias, Het civilisatieproces. Sociogenetische en psychogenetische onderzoekingen, Utrecht 1987.

20. N. Elias, Sociologie en geschiedenis en andere essays, Amsterdam 1971, p. $59=122$.

21. N. Elias, o.c., p. 113.

22. idem, p. 115 .

23. R.H.J. ter Meulen, 'Een individuele substantie met een rationele natuur. Wijsgerige en maatschappelijke achtergronden van het persoonsbegrip in de gezondheidsethiek'. In: M.A.M. de Wachter (ed.) Persona. Het persoonsbegrip in de bio-ethiek. Instituut voor Gezondheidsethiek, Maastricht 1994, p. 22-60.

24. R. Macklin, 'Personhood in the Bioethics Literature', In: Milbank Memorial Fund Quarterly/Health and Society, 61 (1) (1983), p. 35-57.

25. H. Zwart, o.c.

26. A. Mooij, Taal en verlangen. Lacanś theorie van de psychoanalyse. Meppel 1975.

27. M. Foucault, De geboorte van de kliniek. Een archaeologie van de medische blik. Nijmegen 1986.

28. R. Bellah et al, Habits of the Heart, Berkeley 1985; Ch. Lasch, The Culture of Narcissism. American Life in an Age of Diminishing Expectations, New York 1979; Ch. Taylor, The Ethics of Authenticity, Cambridge 1991.

29. J. Jansz, 'Sociale individualiteit', In: De Psycholoog, 26 (1991), p. 541-545.

30. Ph. Cushman, 'Why the Self is Empty. Toward a Historically Situated Psychology', In: American Psychologist, 45 (5) (1990), p.599-611.

31. Ch. Taylor, o.c.

32. N. Elias, o.c., p. 59-122.

33. J. Jansz, Persons, self and moral demands. Individualism contested by collectivism, Leiden 1991.

34. G. Agich, Autonomy and Long-Term Care, p. 76 e.v.

35. R.H.J. ter Meulen, Ziel en Zaligheid. De receptie van de psychologie en van de psychoanalyse onder de katholieken in Nederland 1900-1965, Baarn/Nijmegen 1988.

36. R. Kane \& A. Caplan, Everyday Ethics. Resolving Dilemmas in Nursing Home Life. New York 1990. 
37. K. Charmaz, 'Struggle for a Self: Identity Levels of the Chronically III'. In: J. Roth \& P. Conrad (eds.), Research in the Sociology of Health Care. Vol. 6. Greenwich CT 1987, p. 283-321.

38. P. Sporken, Ethiek en gezondheidszorg, Baarn 1977, p. 100.

39. P. Sporken, o.c., p. 54.

40. H. Manschot \& M. Verkerk (red.), Ethiek van de zorg. Een discussie, Amsterdam/Meppel 1994.

41.J.C. Tronto, Moral Boundaries. A Political Argument for an Ethic of Care, New York 1993, p. 135.

42. HP/De Tijd, De vervagende leeftijdsgrenzen \& het einde van de generatiekloof, 23 juli 1993.

43. J.M. van Meel, De oudere jongere en de jongere oudere. Lezing voor het congres 'Ontgroening en Vergrijzing' op 27 november 1992 te Tilburg, p. 7.

44. J. Jansen van Galen, 'De grenzeloze generatie', In: HP/De Tijd, 23 juli 1993, p. 50-64.

45. Th. Cole, 'Aging, History and Health: Progress and Paradox'. In: J.F. Schroots, J.E. Birren, A. Svanborg (eds.), Health and Aging. Perspectives and Prospects, New York/Lisse 1988, p. 45-63.

46. $\mathrm{R}$, Houtepen, $O p$ zoek naar een goede ouderdom. Liberalisme, communitarisme en gerontologie, Kampen 1993.

47. H. Manschot, o.c.

48. Ch. Taylor, o.c.

49. Ch. Taylor, Sources of the Self. The Making of Modern Identity, Cambridge 1989, p. 34-37. 


\section{Colofon}

ISBN 9070515321

Illustratie omslag:

Jos Hameleers

Grafische verzorging:

Drukkerij Schrijen-Lippertz bv, Voerendaal

(C) Radboudstichting Wetenschappelijk Onderwijsfonds, Vught 